\title{
Pengaruh Teknik Modeling Simbolis Biografi Tokoh Karier Terhadap Pengambilan Keputusan Karier Siswa
}

\author{
${ }^{1}$ Aswidy Wijaya Cipta, ${ }^{2}$ Muhammad Ibrahim ${ }^{3}$ Abdullah Sinring \\ ${ }^{1}$ Psikologi Pendidikan dan Bimbingan, STKIP Muhammadiyah Palopo \\ ${ }^{2,3}$ Psikologi Pendidikan dan Bimbingan, Universitas Negeri Makassar \\ email. ${ }^{1}$ aswidywijayacipta@ stkipmpalopo.ac.id
}

\begin{abstract}
Abstrack: Tujuan penelitian: (1)mengetahui gambaran pengambilan keputusan karier siswa sebelum dan sesudah diberikan pengetahuan tentang pengambilan keputusan karier melalui teknik modeling simbolis menggunakan biografi tokoh karier, (2)mengetahui pengaruh teknik modeling simbolis menggunakan biografi tokoh karier terhadap pengambilan keputusan karier siswa di SMAN 9 Makassar. Penelitian eksperimen ini bersifat kuantitatif dengan Pretest-Posttest Control Group Design terhadap 60 siswa kelas XI IPA. Pengumpulan data menggunakan instrumen angket dan observasi. Analisis data yang digunakan adalah analisis deskriptif, dan analisis statistik inferensial $t$-Test. Hasil penelitian: (1) Gambaran pengaruh teknik modeling simbolis menggunakan biografi tokoh karier yang digunakan dalam pengambilan keputusan karier siswa melalui 4 sesi, yaitu: pemberian informasi mengenai pengambilan keputusan karier, pemberian informasi mengenai modeling simbolis dan biografi, pemberian perlakuan berupa biografi tokoh karier, dan mengikuti kegiatan balikan kelompok. Sebelum diberi teknik modeling simbolis baik kelompok eksperimen maupun kelompok kontrol pada umumnya berada pada kategori rendah. Sesudah diberi perlakuan menunjukkan terjadi perubahan dari tingkat pengambilan keputusan pilihan karier dari rendah menjadi kategori tinggi, sedangkan bagi siswa yang tidak diberi perlakuan tidak menunjukkan perubahan berarti atau tetap dalam kategori sedang. (2) Ada pengaruh signifikan teknik modeling simbolis menggunakan biografi tokoh karier terhadap peningkatan pengambilan keputusan karier siswa di SMA Negeri 9 Makassar.
\end{abstract}

Kata kunci: modelling simbolis, biografi, keputusan karier

\begin{abstract}
Objectives: (1)find out description of the career decision-making students of class XI IPA before and after given knowledge of career decision making through symbolic modeling techniques using biographies, (2)knowing influence of symbolic modeling techniques using biographies against career decision-making of IX IPA students. This is quantitative experimental research with Pretest-Posttest Control Group Design. Data collected using instrument of observation and question form. Data analyzed by descriptive and t-Test. Results: (1)description of the influence of symbolic modeling techniques using biographies career that used in student's career decision making through 4 step, namely: giving information about career decision making, giving information about symbolic modeling and biographies, granting preferential treatment in biographies about career, and follows activities of the group inverse. Before being given symbolic modeling techniques both of experimental group or control group generally are at low category. After being given treatment shows the changes of the level of decision making career choices from low to high, while the categories for students who were not given the treatment showed no change or remain in the middle category. (2) there is significant issue about symbolic modeling techniques using biographies, in case to increased career decision-making student at SMA Negeri 9 Makassar.
\end{abstract}

Keyword: symbolic modelling; biography; career decision making 


\section{PENDAHULUAN}

Siswa yang memiliki kompetensi dan siap untuk memasuki dunia kerja perlu mendapat pendidikan yang telah terspesialisasi sejak dini, hal ini tentunya membutuhkan perencanaan dan kekonsistensi dalam pelaksanaan arah pendidikan yang telah ditentukan. Akan tetapi, di Indonesia kebanyakan yang terlihat selama ini adalah lompatan jalur ilmu. Misalnya, saat SMA mengambil jurusan IPS, kuliah jurusan fisika, dan kemudian bekerja sebagai pegawai Bank. Tenaga kerja dengan jalur pendidikan seperti itu tentunya akan mengalami kesulitan bersaing dalam dunia kerja. Upaya yang ditempuh untuk mengatasi hal tersebut antara lain adalah memberikan modeling simbolis dengan menggunakan biografi tokoh karier terhadap pengambilan keputusan karier. Orientasi pemberian modeling simbolis berupaya mempengaruhi sikap, nilai-nilai dan mengajarkan keterampilan-keterampilan sosial melalui simbol atau gambar dari benda aslinya dan diperuntukkan pada konseli melalui alat-alat perekam. Teknik ini adalah teknik untuk mengubah perilaku dalam pendekatan behavioral untuk mengajarkan konseli tingkah laku yang sesuai, modelnya disajikan melalui media tertentu seperti material tertulis, rekaman audio/video, film/slide. Berdasarkan teori behavioral bahwa kelainan perilaku diakibatkan sebagai kebiasaan yang dipelajari karena itu dapat diubah dengan mengganti situasi positif yang direkayasa sehingga kelainan perilaku berubah menjadi positif (Ginzberg dalam Yuliantari, 2014).

Setelah mewawancarai lebih dari lima siswa pada tanggal 5 Mei 2012 dominan siswa mengemukakan bahwa orang tua mereka belum memberikan kesempatan untuk menentukan pilihan terhadap kariernya. Hal tersebut berkesinambungan dengan survey awal yang dilakukan peneliti di SMAN 9 Makassar dengan berdasar pada hasil wawancara dengan guru BK, diperoleh informasi berbagai problem karier siswa seperti: tidak memiliki perencanaan yang matang ke mana akan mendaftar atau mencari pekerjaan setelah tamat SMA, siswa banyak yang cenderung berdasarkan atas kemauan dan keinginan, ikut-ikutan sama temannya hanya dengan bermodal persahabatan, kurang memahami potensi atau tidak menyesuaikannya dengan bakat dan kemampuan yang dimiliki sehingga sulit menentukan arah kariernya, dan tidak memiliki gambaran yang jelas tentang dunia kerja, bahkan ada siswa yang tidak membuat rencana sama sekali.

Penelitian yang dilakukan oleh Esters \& Bowen tahun 2005 dengan judul Factors Influencing Career Choices of Urban Agricultural Education Students menunjukkan bahwa dari hasil wawancara genogram, diperoleh data tentang siapa yang menjadi tokoh idola siswa dalam keluarganya, dan hasilnya diperoleh data bahwa sebagian besar siswa mengidolakan orang tuanya sebagai inspirasi untuk karirnya, kemudian dalam hal rencana studi siswa memilih untuk melanjutkan ke perguruan tinggi dan akademi, dan untuk rencana pekerjaan siswa banyak memilih pekerjaan sebagai PNS, berwiraswasta, bankir dokter dan ABRI dengan alasan pekerjaan tersebut masih banyak dibutuhkan oleh masyarakat.

Salah satu teknik yang dapat digunakan seorang konselor dalam menangani permasalahan dalam pengambilan keputusan karier tersebut yaitu penggunaan teknik modeling simbolis dalam pendekatan behavioral, tetapi bukan mengarah ke bibliokonseling yang dimana merupakan teknik kognitif yang digunakan konseling REBT untuk mengembangkan akar-akar keyakinan irasional dan logis dengan mempelajari bahan-bahan yang dipilih dan ditentukan oleh konselor.

Gasda mengemukakan bahwa "Modeling adalah metode untuk menghasilkan perilaku baru" (Mappiare, 2006). Salah satu cara yang dapat ditempuh melalui konseling adalah teknik modeling atau pemberian contoh. Abimanyu \& Manrihu (1996) mengutarakan : Modeling simbolis, modelnya disajikan dalam bentuk material tertulis, rekaman audio atau video, film atau slide yang dikembangkan untuk konseli perorangan atau untuk kelompok. Suatu model simbolis dapat mengajarkan konseli tingkah laku yang sesuai, mempengaruhi sikap dan nilai-nilai, dan mengajarkan keterampilan-keterampilan sosial melalui simbol atau gambar dari benda aslinya dan dipertunjukkan pada konseli melalui alat-alat perekam seperti tersebut di atas. Berdasarkan pendapat di atas berkaitan dengan modeling simbolis, maka pada hakikatnya modeling simbolis merupakan suatu prosedur pemberian bantuan kepada orang lain (konseli) dalam upaya memodifikasi pikiran, sikap, dan keyakinan yang dimiliki dengan berdasarkan dengan apa yang ia lihat atau ia dengar. 
Secara umum pengertian biografi merujuk dari Wikipedia bahasa Indonesia dijelaskan bahwa biografi merupakan kisah atau keterangan tentang kehidupan seseorang. Biografi biasanya lebih kompleks dari pada sekedar daftar tanggal lahir atau mati dan datadata pekerjaan seseorang, biografi juga bercerita tentang perasaan yang terlibat dalam mengalami kejadian-kejadian tersebut. Biografi berasal dari bahasa Yunani, yaitu bios yang berarti hidup, dan dab graphien yang berarti tulis. Biografi secara bahasa bisa diartikan sebagai sebuah tulisan tentang kehidupan seseorang, secara sederhana dapat dikatakan sebagai sebuah kisah riwayat hidup seseorang.

Orientasi pemberian modeling simbolis berupaya mempengaruhi sikap, nilai-nilai dan mengajarkan keterampilan-keterampilan sosial melalui simbol atau gambar dari benda aslinya dan diperuntukkan pada konseli melalui alat-alat perekam. Teknik ini adalah teknik untuk mengubah perilaku dalam pendekatan behavioral untuk mengajarkan konseli tingkah laku yang sesuai, modelnya disajikan melalui media tertentu seperti material tertulis, rekaman audio/video, film/slide. Berdasarkan teori behavioral bahwa kelainan perilaku diakibatkan sebagai kebiasaan yang dipelajari karena itu dapat diubah dengan mengganti situasi positif yang direkayasa sehingga kelainan perilaku berubah menjadi positif(Surya, 2003). Upaya yang dilakukan peneliti adalah memberikan satu teknik yaitu teknik modeling simbolis berupa biografi karier, dengan tujuan setelah membaca dan memahami biografi karier siswa dapat meniru perjuangan yang dilakukan oleh tokoh karier yang menginspirasi dunia dan mengaplikasikannya dalam kehidupan pribadinya. Penggunaan modeling simbolis yang dilakukan secara terencana dan intensif dapat memberi dampak positif terhadap peningkatan konseli menghadapi berbagai situasi dalam lingkungan sosialnya. Dalam menyelesaikan masalah yang dihadapi oleh individu khususnya masalah siswa dalam ruang lingkup sekolah, bimbingan dan konseling memiliki pendekatan tersendiri dalam menyelesaikan masalah, olehnya itu alternatif penyelesaian masalah yang dipaparkan dalam penelitian ini adalah dengan teknik modeling simbolis dimana, karena teknik ini dianggap relevan dalam memberikan pemahaman kepada siswa kelas XI IPA SMAN 9 Makassar dimana siswa memerlukan contoh perilaku secara konkret untuk dilihat/diamati sebagai pembelajaran pembentukan tingkah laku konseli. Hal ini dikarenakan juga siswa di sekolah tidak terlepas dari interaksi dengan orang lain, dengan melihat model siswa bisa meniru perilaku yang ditampilkan oleh model simbolis tersebut.

Menurut Luthans dan Davis (ILO, 2008) pengambilan keputusan dapat dipahami sebagai memilih diantara berbagai alternatif. Pengertian ini diperkuat oleh pendapat Garry Deslerr bahwa "Decision is a choice made between available alternatives". Pendapat ini menyebutkan pemikiran yang rasional sebagai hal penting. Dari beberapa pengertian tersebut diatas, terdapat satu kata kunci dalam memahami makna pengambilan keputusan yakni memilih (choice). Penjelasan yang sederhana dari pengambilan keputusan merupakan suatu proses dimana keputusan individu mengadakan suatu seleksi diri dari dua kemungkinan pilihan atau lebih. Seorang siswa dalam kehidupannya akan dihadapkan dalam sejumlah alternatif, baik yang berhubungan dengan diri pribadi, sosial, belajar, ataupun kariernya. Namun adakala siswa mengalami kesulitan untuk mengambil dalam menentukan alternatif mana yang seyogyanya dipilih. Salah satunya adalah kesulitan dalam pengambilan keputusan yang berkenaan dengan rencana pengambilan karier yang akan dipilihnya kelak. Mereka dihadapkan pada pilihan dan permasalahan tentang rencana kariernya. Diantaranya, mereka mempertanyakan, dari sejumlah jenis pekerjaan yang ada pekerjaan apa yang paling cocok untuk saya kelak setelah saya menamatkan pendidikan?

Santi, dkk (2014) juga mengungkapkan bahwa banyak siswa yang cenderung terpengaruh oleh orang lain, tidak percaya diri, kurangnya pengetahuan tentang pekerjaan yang diinginkan, terpaku pada satu pilihan, tidak mampu mengenali bakat dan minatnya, tidak mendapat dukungan dari orang lain, tidak pasti dalam membuat pilihan, dan mengalami masalah berkenaan dengan pekerjaan yang diinginkan. Sedangkan Adiputra (2015) mengungkapkan perkembangan karir merupakan serangkaian perubahan yang terjadi setiap tingkat kehidupan dipengaruhi oleh pemahaman diri (self), nilainilai, sikap, pandangan, kemampuan yang dimiliki dan segala harapan dalam menentukan pilihan karir yang akan dipilihnya, dan merupakan suatu proses yang terjadi karena dipengaruhi oleh faktor 
internal dalam diri pribadi seseorang dan pengaruh faktor eksternal di luar pribadi diri seseorang.

Tujuan penelitian ini dirumuskan sebagai berikut: (1) mengetahui gambaran pengambilan keputusan karier siswa kelas XI IPA SMAN 9 Makassar sebelum dan sesudah diberikan pengetahuan tentang pengambilan keputusan karier melalui teknik modeling simbolis dengan menggunakan biografi tokoh karier, (2) mengetahui pengaruh teknik modeling simbolis dengan mengunakan biografi tokoh karier terhadap pengambilan keputusan karier siswa siswa di SMAN 9 Makassar.

Berdasarkan teori yang di bahas dalam di atas, maka di ajukan hipotesis penelitian ini yaitu ada pengaruh positif teknik Modeling Simbolis dengan menggunakan Biografi tokoh karier terhadap pengambilan keputusan karier siswa kelas XI IPA SMAN 9 Makassar.

\section{METODE}

Pendekatan yang digunakan dalam penelitian ini adalah pendekatan eksperimen yang bersifat kuantitatif. Penelitian yang digunakan adalah True- Experimental Design. Penelitian ini membandingkan pengambilan keputusan karier siswa yang diberikan perlakuan berupa Teknik Modeling Simbolis dengan menggunakan Biografi karier dengan yang tidak diberikan perlakuan di SMAN 9 Makassar. Dengan demikian, dalam penelitian ini ada kelompok eksperimen dan kelompok kontrol yang masing-masing diberikan pretest dan post test. Model rancangan penelitian ini adalah pretest - posttest control group design yang dapat di gambarkan sebagai berikut.

Tabel 3.1 Model Rancangan Penelitian

\begin{tabular}{llll}
\hline Kelompok & Pre test & Perlakuan & Post test \\
\hline Eksperimen (E) & O1 & X1 & O3 \\
\hline Kontrol (K) & O2 & - & O4 \\
\hline (Sumber : Sugiono, 2007) & & 2. & $\begin{array}{l}\text { Pengambilan keputusan karier merupakan } \\
\text { suatu penentuan pilihan karier dengan cara }\end{array}$ \\
Penelitian ini dimaksudkan untuk & menganalisis kesulitan, mengecek keputusan \\
mengkaji dua variabel, yaitu "teknik modeling & $\begin{array}{l}\text { alternatif, dan menentukan pilihan } \\
\text { simbolis dengan menggunakan biografi tokoh }\end{array}$ & $\begin{array}{l}\text { keputusan. } \\
\text { karier" sebagai variabel bebas yang disimbol X }\end{array}$ & Populasi dalam penelitian ini adalah
\end{tabular}
atau yang mempengaruhi, dan "kemampuan pengambilan keputusan karier" sebagai variabel terikat yang disimbol $\mathrm{Y}$ atau yang di pengaruhi.

Definisi operasional merupakan batasanbatasan yang digunakan untuk menghindari perbedaan interpretasi terhadap Variabel yang diteliti dan sekaligus menyamakan persepsi tentang Variabel yang dikaji, maka dikemukakan definisi operasional Variabel penelitian sebagai berikut:

1. Teknik Modeling Simbolis dengan menggunakan Biografi karier adalah suatu prosedur pemberian bantuan kepada konseli dengan cara memperlihatkan model atau bentuk perilaku tertentu yang mana modelnya dibuat dalam bentuk tulisan tentang riwayat hidup serta perjalanan karier tokoh hebat yang menginspirasi dunia dan sukses di bidangnya dengan tujuan mengajarkan konseli tentang bagaimana para tokoh dunia tersebut dalam memantapkan karier pada dirinya. siswa kelas XI IPA SMAN 9 Makassar. Sampel adalah bagian dari jumlah dan karakteristik yang dimiliki oleh populasi, maka ditetapkan untuk dilakukan penelitian pada sampel sebanyak 60 siswa. Karena semua anggota populasi dinilai Homogen, yaitu kelas XI IPA yang berada pada lingkungan sekolah yang sama, pengambilan sampel penelitian dilakukan secara simple random sampling. teknik pengumpulan data yang digunakan dalam penelitian ini adalah angket dan observasi. Bahan perlakuan berupa skenario pelaksanaan modeling simbolis, yang terdiri atas bahan informasi mengenai kemampuan pengambilan keputusan karier dan bahan informasi mengenai modeling simbolis (berisi alasan mengadakan modeling simbolis, tujuan siswa mengikuti modeling simbolis, prosedur yang mesti dilakukan siswa dalam pelaksanaan modeling simbolis, dan alasan siswa harus berpartisipasi aktif dalam kegiatan modeling simbolis), serta bahan informasi mengenai biografi tokoh karier, dan material tertulis berupa biografi tokoh karier yang menginspirasi di 
bidangnya masing-masing. teknik analisis data yang digunakan adalah analisis deskriptif dan analisis t-test.

\section{HASIL DAN PEMBAHASAN}

Berikut ini disajikan data Pengambilan keputusan karier siswa kelas XI IPA di SMAN 9 Makassar pada kelompok eksperimen sebelum dan sesudah penggunaan Teknik Modeling Simbolis dengan menggunakan Biografi tokoh karier yang disajikan dalam bentuk tabel distribusi frekuensi dan persentase dengan berdasarkan data penelitian.

Tabel 4.1 Data Tingkat Pengambilan keputusan karier Siswa SMA Negeri 9 Makassar Kelompok Eksperimen Sebelum (Pretest) dan Setelah (Posttest) Diberi Perlakuan Berupa Pemberian Teknik Modeling Simbolis dengan menggunakan Biografi Tokoh karier.

\begin{tabular}{lcccccc}
\hline \multirow{2}{*}{ Interval } & \multirow{2}{*}{$\begin{array}{c}\text { Tingkat Pengambilan keputusan } \\
\text { karier siswa }\end{array}$} & \multicolumn{4}{c}{ Kelompok Eksperimen } \\
\cline { 3 - 6 } & & Pretest & \multicolumn{2}{c}{ Postest } \\
\cline { 3 - 6 } $146-173$ & Sangat tinggi & 0 & 0 & 3 & $10 \%$ \\
\hline $118-145$ & Tinggi & 0 & 0 & 1 & $3,3 \%$ \\
\hline $90-117$ & Sedang & 30 & $100 \%$ & 0 & 0 \\
\hline $62-89$ & Rendah & 0 & 0 & 0 & 0 \\
\hline $34-61$ & Sangat rendah & & & $\mathbf{1 0 0 \%}$ & $\mathbf{3 0}$ & $\mathbf{1 0 0 \%}$ \\
\hline & & $\mathbf{3 0}$ & & & & \\
\end{tabular}

Sumber : Hasil angket kelompok eksperimen

Pengambilan keputusan karier siswa kelas XI IPA di SMAN 9 Makassar untuk kelompok eksperimen pada saat pretest menunjukkan tidak ada responden yang berada dalam kategori sangat tinggi, kemudian setelah (postest) diberikan perlakuan berupa Teknik Modeling Simbolis dengan menggunakan Biografi tokoh karier, tingkat Pengambilan keputusan karier siswa kelas XI IPA di SMAN 9 Makassar mengalami perubahan dari tidak ada responden dalam kategori sangat tinggi meningkat menjadi 3 responden (10\%), kemudian dalam kategori tinggi pada saat postest mengalami peningkatan yaitu menjadi 26 responden $(86,7 \%)$, disusul kategori sedang sebanyak 1 responden $(3,3 \%)$, dan pada kategori rendah sebanyak 30 responden $(100 \%)$ dan saat postest tidak ada lagi responden yang berada dalam kategori sedang dan rendah. Perubahanperubahan tersebut terjadi dikarenakan siswa telah diberikan teknik modeling simbolis yang terdiri dari 4 sesi pertemuan.
Selama pemberian perlakuan peneliti melakukan observasi terhadap responden. Observasi dilakukan untuk melihat bagaimana gambaran siswa mengikuti kegiatan Teknik Modeling Simbolis dengan menggunakan Biografi tokoh karier. Observasi dilakukan pada 30 siswa yang digolongkan dalam kelompok eksperimen. Selama pelaksanaan kegiatan (teknik modeling simbolis), dalam hal ini, peneliti sebagai konselor dibantu oleh guru pembimbing untuk mengecek lembar observasi. 
Tabel 4.2 Data Tingkat Pengambilan keputusan karirSiswa kelas XI IPA di SMAN 9 Makassar Pada Kelompok Kontrol Hasil Pretest dan Postest

\begin{tabular}{|c|c|c|c|c|c|}
\hline \multirow{3}{*}{ Interval } & \multirow{3}{*}{$\begin{array}{c}\text { Tingkat } \\
\text { Pengambilan } \\
\text { keputusan } \\
\text { karirsiswa }\end{array}$} & \multicolumn{4}{|c|}{ Kelompok Kontrol } \\
\hline & & \multicolumn{2}{|c|}{ Pretest } & \multicolumn{2}{|c|}{ Postest } \\
\hline & & Frekuensi & Persentase & Frekuensi & Persentase \\
\hline 146-173 & Sangat Tinggi & 0 & 0 & 0 & 0 \\
\hline $118-145$ & Tinggi & 0 & 0 & 0 & 0 \\
\hline $90-117$ & Sedang & 12 & $40 \%$ & 14 & $46,7 \%$ \\
\hline $62-89$ & Rendah & 18 & $60 \%$ & 16 & $53,3 \%$ \\
\hline $34-61$ & Sangat Rendah & 0 & 0 & 0 & 0 \\
\hline \multicolumn{2}{|r|}{ Jumlah } & 30 & $100 \%$ & 30 & $100 \%$ \\
\hline
\end{tabular}

Sumber : Hasil angket kelompok kontrol

Pengambilan keputusan karir siswa kelas XI IPA di SMAN 9 Makassar untuk kelompok kontrol hasil pretest dan postest yang diberikan tanpa adanya perlakuan, hasilnya adalah baik pada saat pretest maupun postest tidak ada responden yang berada dalam kategori sangat tinggi dan sangat rendah, selanjutnya untuk kategori tinggi pada saat pretest tidak ada responden yang berada dalam kategori ini, untuk kategori rendah pada saat pretest terdapat $18 \quad(60 \%)$ responden selanjutnya terjadi penurunan menjadi $16(53,3 \%)$ responden berada dalam kategori rendah. Lanjut dalam kategori sedang, pada saat pretest terdapat $12(40 \%)$ responden berada dalam kategori ini, tetapi kemudian pada saat postest terjadi peningkatan menjadi 14 (46,7\%) responden menempati kategori rendah. Pengambilan keputusan karir pada kelompok kontrol tidak menunjukkan banyak peningkatan. Peneliti mencek segala sesuatu yang terjadi dalam proses pelaksanaan kegiatan selanjutnya dianalisis hasilnya. Dari hasil observasi selama pelaksanaan modeling simbolis berlangsung yang dilaksanakan dalam 4 tahap diperoleh data sebagai berikut:

Tabel 4.3 Data Hasil Analisis Persentase Observasi Pelaksanaan Teknik Modeling Simbolis

\begin{tabular}{cccccc}
\hline \multirow{2}{*}{ Persentase } & \multirow{2}{*}{ Kriteria } & \multicolumn{4}{c}{ Pertemuan } \\
\cline { 2 - 6 } & & I & II & III & IV \\
\hline $80 \%-100 \%$ & Sangat tinggi & 1 & 4 & 22 & 30 \\
\hline $60 \%-79 \%$ & Tinggi & 2 & 10 & 8 & 0 \\
\hline $40 \%-59 \%$ & Sedang & 19 & 16 & 0 & 0 \\
\hline $20 \%-39 \%$ & Rendah & 8 & 0 & 0 & 0 \\
\hline $0 \%-19 \%$ & Sangat rendah & 0 & 0 & 0 & 0 \\
\hline \multicolumn{7}{c}{ Jumlah } & 30 & 30 & 30 & 30 \\
\hline
\end{tabular}

Sumber : Hasil angket kelompok eksperimen

Tabel 4.3 menunjukkan data hasil analisis persentase observasi selama pelaksanaan Teknik Modeling Simbolis dengan menggunakan Biografi tokoh karier di SMA Negeri 9 Makassar. Adapun aspek yang diobservasi selama empat kali pertemuan yaitu memperhatikan penjelasan yang diberikan, mengajukan pertanyaan tentang kegiatan yang dilakukan, tenang, mengerjakan tugas yang diberikan, tidak memotong pembicaraan teman, sopan berbicara, mendengarkan pendapat orang lain, tidak melakukan kegiatan lain selama perlakuan, berpartisipasi selama kegiatan berlangsung, sukarela mengikuti kegiatan, memahami dan menyadari pentingnya pengambilan keputusan karier, serta membaca 
dengan seksama biografi tokoh karier yang diberikan.

Berdasarkan tabel dari data hasil analisis persentase observasi pelaksanaan modeling simbolis yang diperoleh maka dapat disimpulkan bahwa disetiap pertemuan terjadi peningkatan partisipasi siswa dalam mengikuti kegiatan Teknik Modeling Simbolis dengan menggunakan Biografi tokoh karier. Meningkatnya partisipasi siswa dalam mengikuti kegiatan juga ikut mendukung terjadinya peningkatan Pengambilan keputusan karier untuk untuk kelompok eksperimen di SMA Negeri 9 Makassar.

Dalam proses penelitian ini kelompok eksperimen diberikan perlakuan berupa teknik modeling simbolis dengan menggunakan biografi tokoh karier yang terdiri dari 4 sesi. Hasil penelitian menunjukkan bahwa tingkat pengambilan keputusan karier siswa sebelum diberikan perlakuan berada pada kategori rendah, akan tetapi setelah diberikan perlakuan berupa teknik modeling simbolis dengan menggunakan biografi tokoh karier tingkat pengambilan keputusan karier siswa mengalami peningkatan atau berada dalam kategori tinggi. Lain halnya dengan kelompok kontrol yang sama sekali tidak diberikan perlakuan ternyata tidak menunjukkan peningkatan yang berarti atau tetap dalam kategori rendah, walaupun ada responden yang telah memiliki tingkat pengambilan keputusan karier yang sedang berdasarkan hasil angket. Hal ini menunjukkan bahwa terdapat pengaruh yang signifikan dari penggunaan teknik modeling simbolis dengan menggunakan biografi tokoh karier terhadap pengambilan keputusan karier siswa setelah diberikan perlakuan. Hasil penelitian di atas sangat relevan dengan hasil penelitian Bandura (Abimanyu dan Manrihu, 1996) bahwa modeling sebagai proses belajar melalui observasi dimana tingkah laku dari seorang individu atau kelompok, sebagai model, berperan sebagai rangsangan bagi pikiranpikiran, sikap-sikap, atau tingkah laku sebagai bagian dari individu lain yang mengobservasi model yang ditampilkan.

Berdasarkan analisis statistik deskriptif yang ada, dapat dianalisis bahwa pada hakekatnya terjadi perubahan tingkat pengambilan keputusan karier bagi kelompok eksperimen yang telah diberi perlakuan berupa teknik modeling simbolis dengan menggunakan biografi tokoh karier dapat dilihat dari perilaku siswa yang sudah mampu memahami dan menyadari pentingnya pengambilan keputusan karier dalam diri mereka sehingga mereka ingin melakukan sesuatu, memiliki keyakinan diri untuk sukses dalam kariernya, dan tidak mudah putus asa dalam melakukannya.

Berdasarkan hasil observasi yang dilakukan selama siswa diberikan perlakuan, diketahui terjadi peningkatan partisipasi siswa dari setiap pertemuan. Perubahan ini terjadi dikarenakan siswa yang diberikan perlakuan cukup antusias mengikuti dan melaksanakan berbagai tahap kegiatan dalam teknik modeling simbolis yang diberikan mulai dari pemberian bahan informasi mengenai pengambilan keputusan karier, kemudian juga mengikuti pemberian informasi mengenai modeling simbolis dan mengenai biografi, membaca biografi tokoh karier, sampai pada kegiatan balikan kelompok, selain itu siswa juga merasa tertarik ingin mengetahui hal-hal yang bisa didapatkan dari kegiatan modeling simbolis. Perubahan ini juga didukung dari hasil kegiatan balikan kelompok yang diketahui sebanyak 30 (100\%) siswa merasa senang mengikuti kegiatan modeling simbolis, karena mereka dapat menambah pengetahuan, dan juga mendapat pengalaman belajar yang baru. Selain, merasa senang, $8(26,7 \%)$ siswa mengalami kesulitan dalam kegiatan modeling simbolis, kesulitan tersebut disebabkan karena siswa malas membaca. Hal ini didukung karena teknik modeling simbolis menggunakan bahan bacaan dalam setiap kegiatannya. $26(86,7 \%)$ siswa tertarik untuk menerapkan modeling dalam kehidupan sehari-harinya, serta 30 (100\%) siswa memberikan kesan yang positif dari pelaksanaan modeling simbolis, mereka juga berharap agar kegiatan modeling simbolis kembali dilaksanakan. Sedangkan kelompok kontrol yang tidak diberikan teknik modeling simbolis dengan menggunakan biografi tokoh karier tidak menunjukkan peningkatan yang berarti, ini dikarenakan siswa pada kelompok kontrol tidak mendapatkan perlakuan berupa teknik modeling simbolis dengan menggunakan biografi tokoh karier yang terdiri dari 4 sesi pertemuan. Sehingga dari 4 sesi pertemuan tersebut siswa pada kelompok kontrol tidak mempunyai kesempatan untuk dapat mengetahui maksud dari pengambilan keputusan karier, tidak mengetahui mengapa modeling simbolis digunakan dan penjelasan mengenai biografi, juga tidak diberi kesempatan untuk membaca biografi tokoh karier serta tidak mengikuti kegiatan balikan kelompok. 
Berdasarkan hasil penelitian, tampak bahwa pelaksanaan teknik modeling simbolis dengan menggunakan biografi tokoh karier merupakan teknik yang dapat meningkatkan pengambilan keputusan karier siswa. Dimana melalui pemberian teknik modeling simbolis dengan menggunakan biografi tokoh karier siswa dapat meniru perilaku yang ditampilkan oleh para model simbolis. Oleh karena itu teknik modeling simbolis perlu diaplikasikan di sekolah-sekolah dalam rangka menyelesaikan permasalahan-permasalahan yang terjadi khususnya masalah pengambilan keputusan karier siswa, sehingga terwujudlah peserta didik yang mampu meraih kesusksesan karier di masa yang akan datang. Pembahasan di atas didukung juga oleh penelitian yang dilakukan Tapip (2008) tentang "program bimbingan dan konseling kecakapan hidup untuk mengembangkan kemantapan karir siswa SMK (studi ke arah pengembangan program BK kecakapan hidup di SMKN 1 Pacet Kabupaten Cianjur)" menyimpulkan profil dimensi sikap kemantapan karir siswa SMK maupun SMA secra umum berada pada kategori tinggi, sedang, rendah. Artinya siswa sudah terlibat pada beberapa aktivitas rencana karir, memiliki keinginan untuk memanfaatkan berbagai sumber informasi karir, namun masih ada sebagian siswa yang cenderung tidak realistik dalam membuat keputusan karir karena belum didasari oleh pemahaman yang cukup baik tentang keadaan diri serta pilihan karir, termasuk belum mampu menjalankan keputusan yang dibuatnya.

\section{SIMPULAN DAN SARAN}

Berdasarkan hasil penelitian mengenai pengaruh teknik modeling simbolis dengan menggunakan biografi tokoh karier terhadap Pengambilan keputusan karier siswa SMA Negeri 9 Makassar, dapat disimpulkan bahwa sebelum diberi perlakuan berupa teknik modeling simbolis baik kelompok eksperimen maupun kelompok kontrol pada umumnya berada pada kategori rendah. Akan tetapi sesudah diberi perlakuan menunjukkan terjadi perubahan dari tingkat pengambilan keputusan karier dari rendah menjadi kategori tinggi, sedangkan bagi siswa yang tidak diberi perlakuan tidak menunjukkan perubahan berarti atau tetap dalam kategori sedang. Kemudian ada pengaruh yang signifikan teknik modeling simbolis dengan menggunakan biografi tokoh karier terhadap peningkatan pengambilan keputusan karier siswa.

Berdasarkan kesimpulan penelitian diatas, maka diajukan saran-saran sebagai berikut: (1) berhubung karena penerapan teknik modeling simbolis dengan menggunakan biografi tokoh karier dalam kegiatan bimbingan dan konseling masih jarang dilaksanakan di sekolah, sedangkan telah terbukti bahwa teknik modeling simbolis ini dapat meningkatkan pengambilan keputusan karier siswa, maka disarankan hendaknya konselor sekolah dapat melaksanakan teknik modeling simbolis dengan mengguanakn biografi tokoh karier secara terprogram. (2) bagi siswa, untuk senantiasa secara mandiri melakukan latihan-latihan berupa membaca biografi tokoh karier yang dapat membantu dalam menyelesaikan masalah khususnya dalam pengambilan keputusan karier yang telah diberikan sebelumnya oleh peneliti, sehingga mampu membuat keputusan kariernya sendiri.

Kepada rekan-rekan mahasiswa dan peneliti, di Jurusan Psikologi Pendidikan dan Bimbingan, agar dapat mengembangkan teknik modeling simbolis dengan menggunakan biografi tokoh karier untuk mengatasi permasalahanpermasalahan yang berbeda pula.

\section{DAFTAR RUJUKAN}

Abimanyu, S \& Manrihu, M T. 1996. Teknik dan Laboratorium Konseling. Jakarta: Departemen Pendidikan dan Kebudayaan Direktorat Jenderal Pendidikan Tinggi Proyek Pendidikan Tenaga Akademik.

Adiputra, S. 2015. Penggunaan Teknik Modeling Terhadap Perencanaan Karir Siswa. Jurnal Fokus Konseling, 1 (1): 45-46

D, E, P, Santi. K, Suranata. K, Dharsana. 2014. Penerapan Konseling Karir Trait dan Factor dengan Menggunakan Teknik Modeling untuk Mengembangkan Rencana Pilihan Karir Siswa Kelas X TPM 1 SMK Negeri 3 Singaraja. Jurnal Undiksha Jurusan BK, 2 (1) 
Esters, L. T. \& Bowen, B. E. 2005. Factors Influencing Career Choices of Urban Agricultural Education Students. Journal of Agricultural Education, 46 (2): 24-35.

ILO. 2008. Pembekalan Pelayanan Bimbingan dan Konseling Karier Bagi Guru Pembimbing SMP, SMA, SMK dan Instruktur Pendidikan Non Formal. Departemen Pendidkan Nasional Direktorat Jenderal PMPTK

Manrihu, T. 1996. Pengantar Bimbingan dan Konseling Karier. Jakarta: Usaha Nasional Indonesia.

Mappiare, A. T. 2006. Kamus Istilah Konseling dan Terapi. Jakarta: PT. Raja Grafindo Persada.

Ni M, Yuliantari. K, Suranata. K, Dharsana. 2014. Penerapan Teori Karir Ginzberg dengan Teknik Modeling untuk Meningkatkan Komitmen Karir pada Siswa Kelas XIA Akuntansi SMK Negeri 1 Singaraja. Jurnal Undiksha Jurusan BK, 2 (1).

Surya, M. 2003. 1993. Teori-Teori Konseling. Bandung: Bani Quraisy.

Tapip. 2008. Program Bimbingan Dan Konseling Kecakapan Hidup Untuk Mengembangkan Kemantapan Karir Siswa SMK (Studi Ke Arah Pengembangan Program BK Kecakapan Hidup Di SMKN 1 Pacet Kabupaten Cianjur). Tidak diterbitkan. Skripsi. Bandung: FIP UPI. 